\title{
Garfinkel Stories
}

\section{Michael Lynch}

Published online: 3 May 2012

(C) Springer Science+Business Media B.V. 2012

Harold Garfinkel was a remarkable character who left a deep impression on those of us who had the opportunity to work with him. He also left behind a legacy of stories that reveal aspects of his large personality, huge ambitions, and unique approach to the academic life. Any of his students, and many others who had extended contact with him, can tell Garfinkel stories. My personal favorite is this one. It took place in 1979 at the Social Science Research Council/British Sociological Association International Conference on Practical Reasoning and Discourse Processes at St. Hugh's College, Oxford. I had finished my $\mathrm{PhD}$ earlier that year, and was presenting a paper based on my dissertation research. It was an ordinary session with around 30 people in the audience. As I recollect from decades later:

Garfinkel is sitting in the front row along with a close colleague of his. I haven't given many presentations at this point in my career, so I'm nervous. About midway through my talk, Garfinkel starts looking agitated, and whispers to his colleague and makes various other motions. I'm not closely watching the commotion, since I'm focused on giving the talk, but I wonder if something I said touched off his agitation. Afterwards when he compliments me on the talk, I ask him about what it was that disturbed him about it. His answer was that it wasn't the talk that bothered him, but that he had thought that a fellow in the audience who had been fiddling with an object placed in his shirt pocket had been secretly recording the presentation. He then said that he (Garfinkel) had leaned over to the fellow and, gesturing toward the item in his shirt pocket, whispered, "Hand me the microphone!" The accused fellow then took an ordinary ballpoint pen from his pocket and showed it to 
Garfinkel. After recounting this incident, Garfinkel added that this would be another "Garfinkel story".

And, so it was and is.

What does this story tell us about Garfinkel? It could, of course, support a diagnosis of what once was called "simple paranoia" (paranoia not accompanied by schizophrenia). However, nothing about Garfinkel was simple. By recounting the story himself, he revealed insight into the incident as well as an ability to laugh about it afterwards. Such insight and self-effacing humor contradict the lack of reflective distance and self-evaluation that define the clinical syndrome. We might also suppose that it was a deliberate "experiment". The incident had an uncanny resemblance to one of Garfinkel's famous "breaching experiments" described in Studies in Ethnomethodology (Garfinkel 1967: 75). In that one, the "experimenter" (no doubt Garfinkel himself) engages a subject in conversation, and then opens his coat to reveal a hidden "wire recorder" (an early audio-recording device), and casually says "See what I have?" Not surprisingly, according to Garfinkel's account of it, subjects reacted with surprise and indignation. What interested Garfinkel about their reactions was that they would refer to the experimenter's action as if it were a violation of a prior agreement, when no such agreement had been made. Paradoxically, the breach constituted the presumption of the prior agreement. Garfinkel's actions during my talk could be viewed as an inverted version of that breaching experiment. In this apparently inadvertent breach, a "subject" accuses an unsuspecting party of harboring a secret tape recorder. Perhaps this could be taken to demonstrate the fragility of the "trust"- the suspension of indefinite possibilities of mistrust-that maintains normal social order in the absence of unequivocal rules (Garfinkel 1963).

Rather than ascribing it to paranoia or an ad hoc "experiment," however, I prefer to draw more specific lessons from the incident. To me, what was startling about it was the way Garfinkel accorded such extraordinary significance to a talk at a professional meeting. His action suggested that my talk could be a source of trade secrets from his "company" (he sometimes used that word). Of course, the talk was important to me, because it was my talk, and I could imagine that it was important to Garfinkel since I was identified as his student, and he would want my work (and by extension his work) to come across well. But, I found it difficult to imagine that anyone else in the room would be so interested in what I had to say that they would try secretly to appropriate my (and Garfinkel's) intellectual property.

It is all too easy to over-interpret this story, or any story, in order to draw practical, theoretical, or biographical lessons. However, to me it was indicative of some recurrent themes in my relationship to Garfinkel during the 1970s and early 1980s, the period when I had most intensive contact with him, initially as a student and then for a few years as a postdoctoral colleague. At the time, Garfinkel was writing extensively, on a daily basis. He was in his office early and he left later than anyone else in the Sociology Department at UCLA. When not meeting students or attending meetings, he was pounding away on his IBM Selectric typewriter or writing copious notes and corrections by hand on pages he had drafted. Every day, he carted a large case of his writings back and forth from his office on a wheeled 
cart. No doubt, he was writing at home as well. However, while the pages piled up relentlessly, he wasn't publishing much at the time and was guarded about revealing to others, including his students, what he was writing.

I only ever saw a tiny proportion of those reams of paper he was typing, but much of what I saw were drafts and redrafts of introductions and outlines for a series of volumes on studies of work by himself and his students. In various introductions and announcements, Garfinkel proposed a radically new approach to studies of workplace activities, including work in the sciences and technical professions, which would encompass the contents of practices and not only the aspects of their organization that traced back to sociology's toolbox of concepts and variables. In other words, the idea was to recover the practical and interactional production of music, scientific experimentation, documentary filming, long-haul truck driving, mathematical proving, classroom teaching, lawyers' arguments, and so forth. Garfinkel used the expression "the missing what" to characterize the way earlier sociological studies had left out the performance of the constituent practices when studying sociological aspects of the arts, sciences, and other organizations of practice.

Versions of some, but by no means all, of these writings were published years later (Garfinkel 1986, 1991, 1996, 2002), but for more than a decade Garfinkel labored over the announcement and outline of the program, while encouraging his students to engage in studies of science, mathematics, law, and various other arts and occupations. The long-term aim not only was to enrich the sociology of the sciences, arts, and other occupations and preoccupations, but to create "hybrid studies" that would be as much a part of the practices studied as they were of sociology. In other words, ethnomethodology would take a distinctive form as it became integrated with the pedagogies and practices of music, law, medicine, mathematics, and so on.

Garfinkel's program for studying work was highly ambitious and selfconsciously "radical" in relation to pre-existing sociological studies. Viewed with hindsight, the program did not create the revolution that Garfinkel had hoped it would, though it has made inroads into various social science fields and subfields, as well as the new "hybrid" field of Computer Supported Cooperative Work (CSCW). During the 1970s and 1980s, however, his ambition to make a radical break with existing sociology was at a peak. That ambition was, of course, preceded (and perhaps fueled) by the publication several years earlier of Studies in Ethnomethodology. The reception of Studies was mixed, to put it mildly. Although, the book was embraced and even celebrated by many readers for having created a startlingly new approach to social phenomena, some of the most prominent sociologists at the time dismissed it as obscurely written and unoriginal. The hostile reactions persisted through the 1970s, as leading sociologists continued to denounce ethnomethodology as an unscientific and unprofessional “cult" (Lewis Coser's 1975 Presidential address to the American Sociological Association represented the height of such denunciations). Garfinkel could anticipate a similar reception for any next major work that he would publish, and I would speculate that such anticipation was in the background of incidents such as the one I recounted earlier. 
As noted earlier, Garfinkel did not have a writer's block; instead, he had what could be called a publication block. Aside from any anticipations of a highly critical and even hostile reception to whatever he might publish, there also may have been a more systematic reason for his distrust of the published word. At the time, he would sometimes show students in his seminars a video of a student (Stacey Burns) typing at a keyboard while sustaining a running commentary as she typed. The videotape recorded mistakes and erasures, and changes in direction of ongoing passages. Garfinkel used the tape to demonstrate what he called Lebenswelt Pairs. This theme recalls the phenomenological life-world, but specifies life-worldly activities in contrast to formal versions of the "same" activities (Garfinkel and Wieder 1992; Garfinkel 2007). The 'pair' consisted of two components: a formal document (the completed typescript in this case) and the 'lived work' of the continuously unfolding writerly actions documented on the video. Garfinkel proposed that the components of the pair were "asymmetric alternates": one could derive from the video how the final text was composed in a continuously unfolding series of actions, but one could not read the final typescript in isolation and recover the "lived work" that produced it, except through the partial and fallible inferential process of reading the signs on the page. If we apply this to Garfinkel's own lived work at the time, the lesson would be that any formal record of the singular, novel, unfolding, and ecstatic project he and his students were developing would be subject to inevitable and irreparable misreadings. This is not a matter of the ever-elusive author's intention, but of the actual production of the formal writing in and through lectures, tutorials with students, repeated sessions at the typewriter, and so on.

The fact that the body of work that would realize his latest set of revolutionary ambitions was unpublished and largely unwritten created recurrent difficulties for those of his students who wanted, indeed needed, to put out publications quickly in order to have any prospect for academic employment. Garfinkel was not one to hide his suspicions, and he frequently expressed suspicions along the following lines:

- He suspected (in many cases, correctly) that his students wanted careers in academic sociology and were less inclined to take their chances with finding space in the unknown, not-yet-established territories of hybrid fields.

- He suspected that his students would appropriate his (and ethnomethodology's) radical initiatives, and would integrate them with professionally accepted topics, concepts, and perspectives, in order to make careers for themselves in sociology.

- He suspected that students would appropriate his ideas, publish them quickly, recharacterize key themes and lines of argument, and then "sell" them to the academic profession under their own names.

- He suspected that students would "skip cite" him and ethnomethodology in their publications by assigning his ideas to respectable scholarly sources and linking ethnomethodology to more established lines of theory and research.

- He suspected that, even when they gave him due credit, students would provide "Bowdlerized" versions of what he had been working out with greater care and diligence in his own, as yet unpublished, writings. The Bowdlerized versions would then become the basis for professionalized (mis)understandings that 
would get in the way of the more challenging and radical initiatives he hoped to launch.

Under the circumstances, these were not unreasonable suspicions. Indeed, he claimed to have been burned at an earlier time by students who preempted Studies in Ethnomethodology with their own (conventionalized) publications. Whether reasonable or not, the suspicions created trouble for his students. For my part, although I will always be deeply indebted to Garfinkel as a mentor and colleague, his suspicions about the published word were a source of edgy relations as we drafted and re-drafted two publications in the early 1980s (Garfinkel et al. 1981; Lynch et al. 1983). I could perhaps say, in retrospect, that my difficulties were part of a tutorial - a test of commitment and seriousness-but that would be to put too kind a gloss on the matter. On that point, I should note that Garfinkel took pride in his own brutal honesty, and would no doubt disdain the kind of euphemistic sendoff that is conventional for memorial speeches and writings.

Toward the end of his life, Garfinkel finally allowed several collections of his writings to be published (Garfinkel 2002, 2006, 2008). Anne Rawls deserves major credit for working with Garfinkel, editing his writings, and persuading him to publish these texts, but in a way they illustrate the suspicions Garfinkel had about formal publication. Although they can be mined for valuable gems, the writing has an unfinished and fragmentary surface appearance. Rawls' lengthy introductions provide illuminating background details, but they also provide highly theorized, and sometimes conventionalized, interpretations of what Garfinkel may have said or meant. Consequently, the author of these recent publications represents, at best, one part of Garfinkel's Lebenswelt pair, and one that he was reluctant to expose in isolation from the "lived work".

The recent publications help to shape Garfinkel's legacy as that of an original and brilliant sociological theorist, whose published and archival writings will preoccupy scholars for years to come. However, while Garfinkel sometimes behaved as a selffashioning genius (and, it must be said, he frequently brought off the act), he often emphasized that he was not interested in taking his place in the pantheon of great sociological theorists and becoming an object of scholarship. Instead, he consistently said he envisioned a sustained and collective line of work for a "company" that would cross disciplinary lines and create new hybrid disciplines, while also pursuing a common (if not "core") set of ethnomethodological initiatives. He also acknowledged that his company was, in his words, "a company of bastards," meaning that it was anarchic and contentious, but also a source of original initiatives as each student found her or his own way. In this there is potential for new turns as well as fragmentation.

In addition to papers, Garfinkel left behind hundreds of hours of recorded conversations with colleagues and students dating back at least to the 1950s. These materials provide the possibility of supplementing his legacy as a theorist with reminders of the other "pair part" of the Lebenswelt Pair: the conversations, arguments, expressions of intense excitement, worried musings, and many other "lived" moments in a unique and contentious academic career. Although Garfinkel has left us after a very long life, he also left us with an unfinished agenda, and the 
ultimate fate of his program is now in our hands. The materials he left behind should fuel his (and "the company's") legacy for many years to come.

\section{References}

Garfinkel, H. (1963). A conception of, and experiments with, "trust" as a condition of stable concerted actions. In O. J. Harvey (Ed.), Motivation and social interaction: Cognitive approaches (pp. 187-238). New York: Ronald Press.

Garfinkel, H. (1967). Studies in ethnomethodology. Englewood Cliffs, NJ: Prentice Hall.

Garfinkel, H. (Ed.). (1986). Ethnomethodological studies of work. London: Routledge \& Kegan Paul.

Garfinkel, H. (1991). Respecification: Evidence for locally produced, naturally accountable phenomena of order, logic, reason, meaning, method, etc. in and as of the essential haecceity of immortal ordinary society (I) - an announcement of studies. In G. Button (Ed.), Ethnomethodology and the human sciences (pp. 10-19). Cambridge, UK: Cambridge University Press.

Garfinkel, H. (1996). Ethnomethodology's program. Social Psychology Quarterly, 59(1), 5-21.

Garfinkel, H. (2002). Ethnomethodology's program: Working out Durkheim's aphorism. Lanham, MD: Rowman and Littlefield.

Garfinkel, H. (2006). Seeing sociologically. Boulder, CO: Paradigm Publishers.

Garfinkel, H. (2007). Lebenswelt origins of the sciences: Working out Durkheim's aphorism. Human Studies, 30, 9-56.

Garfinkel, H. (2008). Toward a sociological theory of information. Boulder, CO: Paradigm Publishers.

Garfinkel, H., Lynch, M., \& Livingston, E. (1981). The work of a discovering science construed with materials from the optically discovered pulsar. Philosophy of the Social Sciences, 11, 131-158.

Garfinkel, H., \& Wieder, D. L. (1992). Two incommensurable, asymmetrically alternate technologies of social analysis. In G. Watson \& R. M. Seiler (Eds.), Text in Context: Contributions to Ethnomethodology (pp. 175-206). London: Sage.

Lynch, M., Livingston, E., \& Garfinkel, H. (1983). Temporal order in laboratory work. In K. KnorrCetina \& M. Mulkay (Eds.), Science Observed (pp. 205-238). London: Sage. 